\title{
Physiological quality of parsley seeds in function of size
}

\section{Qualidade fisiológica de sementes de salsa em função do tamanho}

\author{
Renato Téo de Barros ${ }^{1 *}$; Cibele Chalita Martins ${ }^{2}$; Tatiane Sanches Jeromini1; \\ Givanildo Zildo da Silva ${ }^{3}$; Arthur Bernardes Cecílio Filho²
}

\section{Highlights}

Large parsley seeds show greater vigor and success in stand establishment.

The size of parsley seeds influences their physiological quality.

Sieves with 1.41 mesh opening can be used to classify parsley seeds.

\begin{abstract}
Parsley seeds are commercialized without classification by size during processing, unlike other crops. This classification procedure allows the standardization of seed size for high precision in sowing, disposal of unwanted material, and selection of high quality seeds. The aim of this study was to verify the effect of seed size on germination, vigor, and yield performance of two parsley cultivars. Seeds from eight lots of parsley of 'Portuguesa' and 'Chacareira' cultivar were separated into three size classes, represented by the seeds retained in the sieves of $0.84,1.00$ and $1.41 \mathrm{~mm}$ mesh opening. After classification, seeds were evaluated in the laboratory for water content, germination percentage, first count, and thousand seed weight. In the field, the fresh and dry weight of aerial part and the final number of plants (stand) were evaluated after 78 days of sowing. The experimental design was the completely randomized design in an $8 \times 3$ factorial scheme (eight lots and three sieve opening) with four replicates, for both cultivars. Data obtained were subjected to analysis of variance and means were compared using Tukey test at $5 \%$ probability level. It was concluded that the parsley seeds separated by the $1.41 \mathrm{~mm}$ sieves showed higher vigor, and consequently, greater success in stand establishment at the field than those separated by other sieve size. The use of sieves in the classification of parsley seeds helps in obtaining lots with superior physiological quality.
\end{abstract}

Key words: Germination. Petroselinum crispum (Mill.). Processing. Sifting. Vigor.

${ }^{1}$ PhD Students of Graduate Program in Agronomy, Plant Production, Universidade Estadual Paulista "Júlio de Mesquita Filho", Faculdade de Ciências Agrárias e Veterinárias, UNESP/FCAV, Jaboticabal, SP, Brazil. E-mail: renato. barros@unesp.br; tatiane_jeromini@hotmail.com

2 Profs. Livre-Docente, UNESP/FCAV, Jaboticabal, SP, Brazil. E-mail: cibele.chalita@unesp.br; arthur.cecilio@unesp.br

${ }^{3}$ Prof., Graduate Program, Universidade Federal de Goiás, UFG, Regional de Jataí, Jataí, GO, Brazil. E-mail: givanildozildo@hotmail.com

* Author for correspondence

Received: Aug. 30, 2020 - Approved: Nov. 04, 2020 


\section{Resumo}

As sementes de salsa são comercializadas sem a classificação por tamanho no beneficiamento, diferentemente de outras hortaliças. Este procedimento permite a padronização do tamanho para a maior precisão na semeadura, descarte de material indesejado e seleção de sementes de maior qualidade. Objetivou-se com este trabalho avaliar o efeito do tamanho da semente na germinação, vigor e desempenho produtivo em campo de duas cultivares de salsa. Sementes de oito lotes de salsa da cultivar 'Portuguesa' e 'Chacareira' foram separadas em três classes de tamanho representadas por sementes retidas nas peneiras com abertura de malha de 0,84, 1,00 e 1,41 mm. Após a classificação, as sementes foram avaliadas em laboratório quanto ao teor de água, porcentagem de germinação, primeira contagem de germinação e massa de mil sementes. No campo, avaliou-se após 78 dias da semeadura o número final de plantas (estande), massa de matéria fresca e a massa de matéria seca da parte aérea. $O$ delineamento utilizado foi o inteiramente casualizado no esquema fatorial $8 \times 3$ (oito lotes e três aberturas de peneira) com quatro repetições, para as duas cultivares utilizadas. Os dados foram submetidos à análise de variância e as médias comparadas pelo teste de Tukey a $5 \%$ de probabilidade. Concluiu-se que sementes de salsa classificadas nas peneiras de 1,41 mm apresentam maior vigor e, consecutivamente, maior sucesso no estabelecimento do estande a nível de campo. O uso de peneiras na classificação de sementes de salsa permite a obtenção de lotes com qualidade fisiológica superior.

Palavras-chave: Beneficiamento. Germinação. Peneiramento. Petroselinum crispum (Mill). Vigor.

\section{Introduction}

Petroselinum crispum (Mill.) Nyman ex A.W. Hill (Apiacea), also known as parsley, is a biennial herbaceous plant that can be cultivated as an annual plant. The species is one of the most popular aromatic herbs in gastronomy because its fresh or dehydrated leaves are used as condiment (Corrêa, Martinazzo, Teodoro, \& Andrade, 2018). In addition to its commercial relevance, parsley is also known as an important source of vitamins, flavonoids, and carotenoids (Maodaa et al., 2016).

Parsley is a species that emits inflorescences over time; therefore, the maturation of the seeds of different umbels also occurs unevenly. At harvest, its lot is formed from a mixture of seeds from different umbels. The vegetable seeds that are harvested immature in some cases have low germination rate and vigor (Miranda, Dias, Picoli, Silva, \& Nascimento, 2017; F. E. C. B. Pereira, Torres, Silva, Granjeiro, \& Benedito, 2014; Silva, Sekita, Dias, \& Nascimento, 2016).

It was found that larger carrot seeds (Daucus carota, Apiaceae family) presented higher percentage of germination and emergence in the field. In addition, larger seeds produced more vigorous seedlings than small seeds (R. S. Pereira, Nascimento, \& Vieira, 2008). According to the same authors, such performance could be attributed to the large embryos and the amount of reserves that large carrot seeds have for the germination process. However, Gomes et al. (2012) found no difference in dry weight of carrot root and shoot and yield using seeds of different size classes. Thus, size, vigor, and germination of carrot seeds was related to the lot and genetics of the plant (R. S. Pereira et al., 2008). 
The effects of seed vigor on seedling emergence can be critical for vegetables, as species with shorter cycle, which require less time between sowing and harvest, maintain greater residual effect of seed vigor and, possibly, respond more clearly to the vigor than species with longer cycle (Hanumaiah \& Andrews, 1973; Marcos, 2015). In addition, the delay of stand establishment can change the uniformity of plant growth, which is an important characteristic, and the product of some vegetable harvest is the vegetative part (Marcos, 2015), as in the case of parsley.

To some vegetables, the effects of seed vigor on plant performance may be evident at the beginning of development; however, they may reduce with the advancement of phenological stages, and at the end of the crop cycle, they do not affect production, as it was reported for onion, radish, and carrot (Marcos \& Kikuti, 2006; Martins, Silva, \& Machado, 2013). Conversely, for cauliflower, depending on the cultivar and time of sowing, their seed size affected their yield (Cardoso \& Silva, 2009).

Thus, this study aimed to verify the effect of seed size on germination, vigor, and yield of two parsley cultivars.

\section{Material and Methods}

Parsley seeds of 'Portuguesa' and 'Chacareira' cultivars were harvested using hand; eight lots of each cultivar were obtained from the blend of seeds collected from all the umbels of individual plants after natural drying.

The lots were sent to the Seed Analysis Laboratory of the Crop Production Department at Faculdade de Ciências Agrárias e Veteriárias (UNESP), Jaboticabal campus, where the seeds of each lot were classified using braided mesh sieves with square holes of $0.84 \times 0.84$ $\mathrm{mm}, 1.00 \times 1.00 \mathrm{~mm}$, and $1.41 \times 1.41 \mathrm{~mm}$ of opening, and seeds between 0.84 and 1.00 $\mathrm{mm}$ (small), 1.00 and $1.41 \mathrm{~mm}$ (medium), and larger than $1.41 \mathrm{~mm}$ (large), respectively, were obtained. Two experiments were carried out for each cultivar using the completely randomized experimental design in a 3x8 factorial scheme (seed size $x$ lot) with four replicates. For quality evaluation, the seeds were submitted to the following determinations and tests:

Water content - determined using two sub-samples of $0.5 \mathrm{~g}$ of each lot, using the high temperature oven method for a short exposure period $\left(130 \pm 3{ }^{\circ} \mathrm{C} / 1 \mathrm{~h}\right)$, and the results were expressed in percentage (Ministério da Agricultura, Pecuária e Abastecimento [MAPA], 2009).

Thousand seed weight - obtained using eight sub-samples of 100 seeds weighed on a precision scale $(0.0001 \mathrm{~g})$. The calculation was performed according to the report of (MAPA, 2009) and the results were expressed in grams.

Germination test - performed with four sub-samples of 50 seeds arranged on two sheets of germination paper previously moistened with 2.5 times the mass of the paper in water, in transparent plastic boxes $(11.0 \mathrm{x}$ $11.0 \times 3.5 \mathrm{~cm})$. The test was performed at $20^{\circ} \mathrm{C}$ and photoperiod of 8 hours. Germinated seeds were considered to be those that produced normal seedlings, counted on the 10th and 28th day after sowing and the result was expressed in percentage (MAPA, 2009).

First germination count - performed together with the germination test, where normal seedlings were counted on the 10th day after sowing (MAPA, 2009). 
For evaluation in the field, the test was performed in a eutrophic Red Latosol with a heavy clay texture inside a greenhouse covered with transparent polyethylene of 150 $\mu \mathrm{m}$ thickness. Additionally, fertilization was dispensed owing to the nutritional content of the soil appropriated for the crop, which was verified by chemical analysis of the soil at a depth of $0-20 \mathrm{~cm}$ (Table 1). Irrigation was carried out daily using a drip system in a 45-minute watering shift and an application of $5.5 \mathrm{~L} . \mathrm{m}^{-2}$. The plots were distributed using the completely randomized experimental design with four replicates.

Table 1

Result of chemical analysis of greenhouse soil

\begin{tabular}{|c|c|c|c|c|c|c|c|c|}
\hline $\mathrm{pH}$ & O.M. & P resin & K & $\mathrm{Ca}$ & $\mathrm{Mg}$ & $\mathrm{H}+\mathrm{Al}$ & SB & V \\
\hline $\mathrm{CaCl}_{2}$ & $\mathrm{~g} \mathrm{dm}^{-3}$ & $\mathrm{mg} \mathrm{dm}^{-3}$ & & - & olc C & 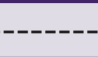 & & $\%$ \\
\hline 5.4 & 18 & 92 & 2.7 & 32 & 8 & 17 & 42.7 & 62 \\
\hline
\end{tabular}

Sowing was carried out by distributing 50 seeds in furrows of one meter, with a spacing of 20 centimeters between them, and was done in four replicates. Harvest was carried out at the end of the crop cycle, 78 days after sowing, when the number of plants in each sowing line was counted.

Fresh and dry weight - the fresh weight was obtained by weighing the aerial part of all plants immediately after harvest. The dry weight was obtained after drying the aerial part in an oven with forced air circulation at $65^{\circ} \mathrm{C}$ for 48 hours and weighing on a precision scale $(0.01 \mathrm{~g})$. The results were expressed in grams per plant.

The obtained data were subjected to normality and homogeneity analysis using Shapiro-Wilk test and then subjected to F test.
When significant, the treatment means were compared using Tukey test at 5\% probability.

\section{Results and Discussion}

The water content of parsley seeds of both cultivars was between 8.5 and $10.8 \%$; the values were similar to those verified when they arrived from the seed processing units (Carvalho \& Nakagawa, 2012). Uniform values of water content are essential for the validation of tests and evaluation of the physiological quality of seeds (Bisognin et al., 2016).

As shown in Table 2, there was a significant interaction between lots and seed size for all variables analyzed, both for Portuguesa and Chacareira cultivar. 


\section{Table 2}

Summary of analysis of variance of thousand seed weight (TSW), germination (G), first count of germination (FC), number of plants (NP), fresh weight (FW), and dry weight (DW) of Parsley of different sizes and lots

\begin{tabular}{|c|c|c|c|c|c|c|c|}
\hline \multirow{3}{*}{$\begin{array}{l}\text { Source of } \\
\text { Variation }\end{array}$} & \multirow{3}{*}{ D.F. } & \multicolumn{6}{|c|}{ Mean Square } \\
\hline & & \multicolumn{6}{|c|}{ 'Portuguesa' Cultivar } \\
\hline & & TSW & $\mathrm{G}$ & FC & NP & $\mathrm{FW}$ & DW \\
\hline Size (S) & 2 & $0.503^{* *}$ & $1216.16^{* *}$ & $1848.87^{* *}$ & $4362.51^{\text {** }}$ & $0.27^{* *}$ & $0.005^{* *}$ \\
\hline Lot (L) & 7 & $0.020^{* *}$ & $1657.56^{* *}$ & $4243.04^{* *}$ & $226.76^{* *}$ & $0.47^{* *}$ & $0.011^{* *}$ \\
\hline SxL & 14 & $0.003^{* *}$ & $195.97^{* *}$ & $348.68^{* *}$ & $54.64^{*}$ & $0.20^{* *}$ & $0.005^{* *}$ \\
\hline Residual & 72 & 0.00001 & 60.37 & 67.45 & 24.39 & 0.04 & 0.0008 \\
\hline \multirow[t]{2}{*}{ CV (\%) } & - & 2.15 & 11.69 & 14.27 & 19.59 & 34.62 & 31.11 \\
\hline & & \multicolumn{6}{|c|}{ 'Chacareira' Cultivar } \\
\hline Size (S) & 2 & $21.787^{* *}$ & $609.29 * *$ & $2431.54^{* *}$ & $1210.82^{* *}$ & $0.35^{* *}$ & $0.003 n s$ \\
\hline Lot (L) & 7 & $0.339 * *$ & $213.94^{* *}$ & $1460.56^{* *}$ & $213.02^{* *}$ & $1.32^{* *}$ & $0.023^{* *}$ \\
\hline$S x L$ & 14 & $0.136^{* *}$ & $137.91^{* *}$ & $995.20 * *$ & $48.25^{*}$ & $0.21^{* *}$ & $0.004^{* *}$ \\
\hline Residual & 72 & 0.007 & 14.56 & 53.59 & 25.32 & 0.06 & 0.001 \\
\hline CV (\%) & - & 4.26 & 4.25 & 8.73 & 12.8 & 27.97 & 26.86 \\
\hline
\end{tabular}

** and * - significant at $1 \%$ and $5 \%$ level of probability by the $\mathrm{F}$ test, respectively.

It was found in both cultivars that the larger the seed size, the greater the weight of a thousand seeds (Table 3). Seed size is related to the amount of reserve material, physiological maturity, and embryonic formation and this relationship probably provide superior physiological quality in large seeds (Carvalho \& Nakagawa, 2012; F. E. C. B. Pereira et al., 2014; W. A. Pereira, Pereira, \& Dias, 2013).

There was weight difference between the lots evaluated within the classes. Even with the selection of seeds according to size, there is still a variation in weight between the lots. During processing, this variation can be mitigated with the use of gravitational tables after the use of sieves. In addition to standardizing the size, there will also be weight standardization. Thus, farmers will acquire a high quality product as observed for other seeds (Melo, Martins, Silva, Pereira, \& Jeromini, 2018; Jeromini, Martins, Pereira, \& Gomes, 2019). 
Table 3

Thousand seed weight (TSW) of small $(\mathrm{S}-0.84 \geq 1.0 \mathrm{~mm})$, medium $(\mathrm{M}-1.0 \geq 1.41 \mathrm{~mm})$, and large $(\mathrm{L}->$ $1,41 \mathrm{~mm}$ ) parsley seeds from eight lots of Portuguesa and Chacareira cultivar

\begin{tabular}{|c|c|c|c|c|c|c|c|c|c|}
\hline \multirow[b]{2}{*}{ Cultivar } & & \multicolumn{8}{|c|}{ Lots } \\
\hline & & 1 & 2 & 3 & 4 & 5 & 6 & 7 & 8 \\
\hline \multirow{3}{*}{$\begin{array}{c}\text { 'Portuguesa' } \\
\text { TSW (g) }\end{array}$} & $S$ & $0.88 \mathrm{cF}$ & 0.92 c EF & $0.98 \mathrm{c} E$ & $1.17 \mathrm{c} \mathrm{AB}$ & 1.07 c D & $1.23 \mathrm{c} \mathrm{A}$ & 1.16 c BC & $1.10 \mathrm{c} \mathrm{CD}$ \\
\hline & M & $1.28 \mathrm{~b} \mathrm{~F}$ & $1.31 \mathrm{~b} \mathrm{~F}$ & $1.74 \mathrm{~b} \mathrm{D}$ & $2.06 \mathrm{~b} \mathrm{~A}$ & $1.64 \mathrm{bE}$ & 1.96 b B & 1.88 b C & $1.68 \mathrm{~b} \mathrm{E}$ \\
\hline & $\mathrm{L}$ & $2.03 \mathrm{a} \mathrm{G}$ & 2.09 a F & $2.85 \mathrm{a} E$ & 3.22 a A & 3.14 a B & 3.23 a A & 3.03 a C & 2.93 a D \\
\hline \multirow{3}{*}{$\begin{array}{c}\text { 'Chacareira' } \\
\text { TSW (g) }\end{array}$} & $S$ & $1.34 \mathrm{c} \mathrm{BC}$ & $1.36 \mathrm{c} \mathrm{BC}$ & 1.33 c BC & $1.46 \mathrm{c} \mathrm{AB}$ & 1.30 c C & 1.33 c BC & 1.39 с BC & 1.53 c A \\
\hline & M & 1.78 b A & $1.62 \mathrm{~b} \mathrm{BC}$ & $1.59 \mathrm{~b} \mathrm{BC}$ & $1.64 \mathrm{~b} \mathrm{BC}$ & $1.62 \mathrm{~b} \mathrm{BC}$ & $1.71 \mathrm{~b} \mathrm{AB}$ & 1.57 b C & $1.77 \mathrm{~b} \mathrm{~A}$ \\
\hline & L & 2.64 a B & 2.42 a C & 2.54 a BC & 2.44 a C & 1.98 a D & 2.58 a B & 2.54 a BC & 2.87 a A \\
\hline
\end{tabular}

Means followed by the same lowercase letter in the column and uppercase letter in the row do not differ statistically from each other based on Tukey test at $5 \%$ probability.

Seeds of both cultivars showed similar behavior in relation to germination percentage (Table 4). For most lots of Portuguesa Cultivar $(1,2,3,4$, and 6$)$, germination was not affected by seed size. Although, lots 5, 7, and 8 showed greater germination of large seeds, the medium seeds of lot 7 did not differ from the large ones.

Table 4

Germination percentage $(G)$ of small $(S-0.84 \geq 1.0 \mathrm{~mm})$, medium $(\mathrm{M}-1.0 \geq 1.41 \mathrm{~mm})$, and large $(\mathrm{L}->1.41$ $\mathrm{mm}$ ) parsley seeds from eight lots of Portuguesa and Chacareira cultivar

\begin{tabular}{|c|c|c|c|c|c|c|c|c|c|}
\hline \multirow[b]{2}{*}{ Cultivar } & & \multicolumn{8}{|c|}{ Lots } \\
\hline & & 1 & 2 & 3 & 4 & 5 & 6 & 7 & 8 \\
\hline \multirow{3}{*}{$\begin{array}{c}\text { 'Portuguesa' } \\
\text { G (\%) }\end{array}$} & S & 68.5 a $A B$ & 73.0 a A & 64.0 a $A B C$ & 43.0 a D & 55.0 b BCD & 70.0 a $A B$ & 65.5 b ABC & 49.5 c CD \\
\hline & M & 65.5 a $A B$ & 73.0 a A & 70.0 a A & 38.5 a C & 52.5 b BC & 79.0 a A & $75.5 \mathrm{ab} A$ & $67.5 \mathrm{~b}$ AB \\
\hline & L & 75.5 a $A B$ & 76.5 a $A B$ & 67.0 a B & 40.0 a $C$ & 76.0 a $A B$ & 80.0 a $A B$ & 88.0 a A & 83.0 a $A B$ \\
\hline \multirow{3}{*}{$\begin{array}{c}\text { 'Chacareira' } \\
\text { G (\%) }\end{array}$} & S & 80.5 b BC & 95.5 a A & 78.0 c CD & 70.0 c D & 95.0 a A & 80.5 b BC & 93.5 a A & 87.5 a $A B$ \\
\hline & M & 93.5 a A & 94.5 a A & 90.5 b AB & 82.5 b B & 91.5 a A & 89.5 a $A B$ & 91.0 a A & 88.0 a $A B$ \\
\hline & L & 92.5 a $A B C$ & 98.0 a $A B$ & 99.0 a A & 97.5 a $A B$ & 96.5 a $A B$ & 90.0 a BC & 91.5 a $A B C$ & 85.5 a C \\
\hline
\end{tabular}

Means followed by the same lowercase letter in the column and uppercase letter in the row do not differ statistically from each other based on Tukey test at $5 \%$ probability.

For the Chacareira cultivar, four lots $(2$, 5,7 , and 8) were not affected by their seed size. Lots $1,3,4$, and 6 showed superior germination performance with larger seeds than other lots; however, for lots 1 and 6, their medium seeds did not differ from their large ones in the test.
This outcome can be attributed to the ideal conditions of the germination test, which allowed seeds with different levels of vigor to present similar values of germination, and germinative potential is the last characteristic to be lost during a deterioration process. 
Santos, Garcia, Lopes and Eichelberger (2010) also reported that there were no differences in the germination percentages between carrot seeds of different sizes.

The first germination count test (Table 5) with Portuguesa cultivar revealed the effect of seed size on the physiological potential.
Three lots (1, 2, and 3) were not influenced by the size classification of sieves. Half of the lots $(4,5,7$, and 8$)$ showed that large seeds had greater vigor than small and medium ones. In lot 6 , the best result was obtained with medium and large seeds.

\section{Table 5}

First Count of Germination (FC) of small (S - $0.84 \geq 1.0 \mathrm{~mm}$ ), medium (M - $1.0 \geq 1.41 \mathrm{~mm})$, and large ( $\mathrm{L}->$ $1.41 \mathrm{~mm}$ ) parsley seeds from eight lots of Portuguesa and Chacareira cultivar

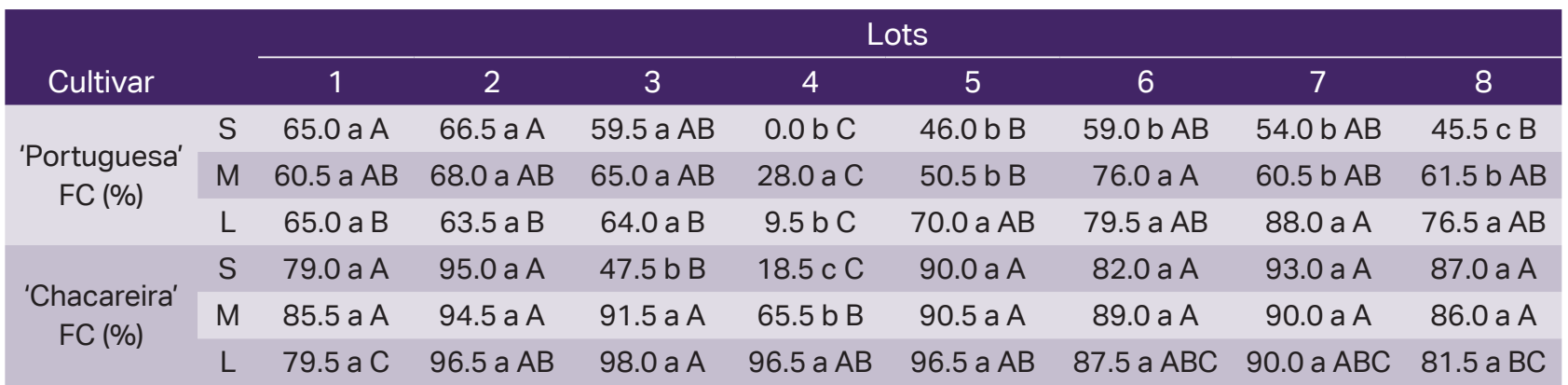

Means followed by the same lowercase letter in the column and uppercase letter in the row do not differ statistically from each other based on Tukey test at $5 \%$ probability.

The superior performance of the largest seeds in the germination and first count test can be explained by the great quantity of reserves that they present, which is revealed by the mass of a thousand seeds (Table 3). The reserves, after going through enzymatic breakdown, are used to resume the growth of the embryonic axis. Thus, the greater the reserves, the greater the speed and germinative potential of the seeds (Marcos, 2015).

The first count is a vigor test that is related to germination speed, and is a characteristic that may be used to determine the survival of plants in fields. The initial stage of the crop, where seeds still depends on their reserves to complete their germination process and become plants, is where the biggest susceptibility to adverse environmental factors, such as water deficit and attack by pests and diseases attacks occur (Carvalho \& Nakagawa, 2012), that is, seed lots that present a higher percentage of germination in their first count have better stand in the field and justifies the seed classification by size.

The effect of classification of seeds by size in the Chacareira cultivar was less evident. For most lots $(1,2,5,6,7$, and 8), there was no difference in seed size in the first germination count; however, in lot 3 , the best performance was obtained with medium and large seeds. The best performance in lot 4 was obtained with large seeds, followed by the medium ones. 
The subtle effect of classification by size on the seeds of Chacareira cultivar in the first count test can be explained by the difference in the initial vigor of seeds. Genetic materials with low initial vigor would be more affected by classification of seed by size, as was probably the case of Portuguesa Cultivar. Vigor is not only influenced by the morphological and physiological characteristics of seeds, because genotype can also affect the physiological quality (Oliveira, Martins, Pereira, Lopes, \& Torres, 2017).

It was revealed that the implantation of parsley beds with large seeds (larger than $1.41 \mathrm{~mm}$ ) ensured higher plant survival in greenhouse conditions for both cultivars (Table 6).

For the Portuguesa cultivar, all lots had a high number of plants when large seeds were used for sowing. The medium and small seeds resulted in a lower number of plants than the large seeds for lots $1,2,4,5,6$, and 7, while for lots 3 and 8 , the small seeds resulted in a lower number of plants than the medium seeds. In the Chacareira cultivar, the same effect was observed. Superior results were obtained with large seeds in lots $2,3,4,5,6$, and 8 than in other lots, and for lots 3 and 4 , the medium seeds did not differ from the large ones.

\section{Table 6}

Number of plants (NP) obtained with small $(\mathrm{S}-0.84 \geq 1.0 \mathrm{~mm})$, medium $(\mathrm{M}-1.0 \geq 1.41 \mathrm{~mm})$, and large $(\mathrm{L}->1.41 \mathrm{~mm})$ parsley seeds from eight lots of Portuguesa and Chacareira cultivar

\begin{tabular}{|c|c|c|c|c|c|c|c|c|c|}
\hline \multirow{2}{*}{ Cultivar } & & \multicolumn{8}{|c|}{ Lots } \\
\hline & & 1 & 2 & 3 & 4 & 5 & 6 & 7 & 8 \\
\hline \multirow{3}{*}{$\begin{array}{c}\text { 'Portuguesa' } \\
\text { NP }\end{array}$} & $\mathrm{S}$ & $14.0 \mathrm{~b} \mathrm{AB}$ & $16.0 \mathrm{~b} \mathrm{AB}$ & $15.2 \mathrm{c} \mathrm{AB}$ & 11.5 b B & $18.0 \mathrm{~b} \mathrm{AB}$ & $20.0 \mathrm{~b}$ AB & $24.0 \mathrm{~b} \mathrm{~A}$ & 13.0 c B \\
\hline & M & $15.1 \mathrm{~b}$ AB & 14.7 b B & $25.5 \mathrm{~b} A B$ & $18.2 \mathrm{~b} A B$ & $18.2 \mathrm{~b} A B$ & $23.7 \mathrm{~b} A B$ & $26.0 \mathrm{~b} \mathrm{~A}$ & $23.5 \mathrm{~b} A B$ \\
\hline & $\mathrm{L}$ & 36.7 a BC & 37.2 a BC & 35.5 a BC & 28.7 a C & 35.0 a BC & 38.0 a BC & 51.2 a $A$ & 45.2 a $A B$ \\
\hline \multirow{3}{*}{$\begin{array}{c}\text { 'Chacareira' } \\
\text { NP }\end{array}$} & $\mathrm{S}$ & 31.2 a A & 31.7 b A & $40.2 \mathrm{~b} \mathrm{~A}$ & 39.0 b A & 35.5 b A & 36.5 b A & 36.7 a A & 29.2 b A \\
\hline & M & 31.5 a BC & 36.5 b ABC & $43.2 \mathrm{ab} A$ & $42.2 \mathrm{ab} A B$ & 39.7 b AB & 37.5 b ABC & 33.2 a $A B C$ & 28.0 b C \\
\hline & $\mathrm{L}$ & 36.5 a A & 48.2 a $A B$ & 50.0 a A & 50.0 a A & 50.0 a A & 50.0 a A & 37.5 a BC & 48.5 a $A B$ \\
\hline
\end{tabular}

Means followed by the same lowercase letter in the column and uppercase letter in the row do not differ statistically from each other based on Tukey test at $5 \%$ probability.

In crops with a short cycle, such as vegetables, seed vigor can affect their yield, since characteristics such as germination speed and final stand relies on vigor (Carvalho \& Nakagawa, 2012; Marcos, 2015). The final population of plants is even more important in crops, in which the harvested parts are the leaves, as in the case of parsley.
In the fresh matter mass test (Table 7), seed size had no effect in most of the lots $(2,3$, 4, 5, and 8) of Portuguesa cultivar; however, in lots 1 and 7, smaller seeds provided superior fresh weight per plant. In lot 6 , the best results were obtained by sowing medium and large size seeds. 
In crops with a short cycle, such as vegetables, seed vigor can affect their yield since characteristics such as germination speed and final stand relies on vigor (Carvalho \& Nakagawa, 2012; Marcos, 2015). The final population of plants is even more important in crops, in which the harvested parts are the leaves, as in the case of parsley.
In the fresh matter mass test (Table 7), seed size had no effect in most of the lots $(2,3$, 4,5 , and 8) of Portuguesa cultivar; however, in lots 1 and 7, smaller seeds provided superior fresh weight per plant. In lot 6 , the best results were obtained by sowing medium and large size seeds.

\section{Table 7}

Fresh weight (FW) per plant obtained with small $(S-0.84 \geq 1.0 \mathrm{~mm})$, medium $(\mathrm{M}-1.0 \geq 1.41 \mathrm{~mm})$, and large $(\mathrm{L}->1.41 \mathrm{~mm})$ parsley seeds from eight lots of Portuguesa and Chacareira cultivar

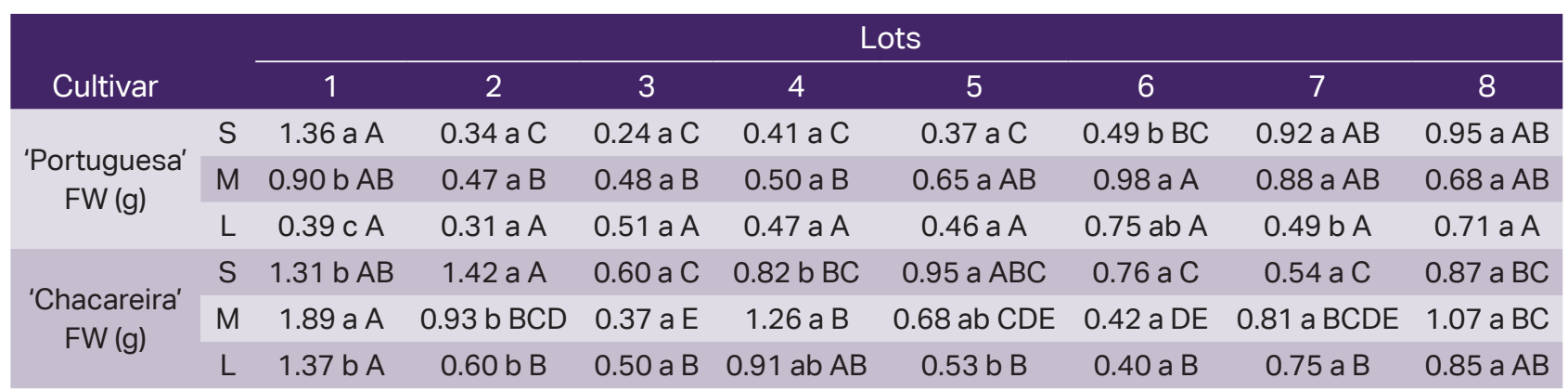

Means followed by the same lowercase letter in the column and uppercase letter in the row do not differ statistically from each other based on Tukey test at $5 \%$ probability.

For Chacareira cultivar, result similar to that of Portuguesa seeds was obtained. In lots $3,6,7$, and 8 , there was no effect of seed size on fresh matter mass, while in lots 2 and 5 , superior results were obtained with small seeds, and for the latter, the small seeds did not differ from the medium ones. The best result was obtained with medium seeds in lot 1 and with medium and large seeds in lot 4.
The result of dry weight test (Table 8) was similar to the result of fresh weight test (Table 7) for both cultivars. In Portuguesa seeds, seed size had no effect in most of the lots $(2,3,4,5$, and 8$)$. In lots 1 and 7 , the best results were obtained with small seeds, and for the latter, there was no difference with the medium ones. In lot 6 , the highest dry weight was obtained with medium-sized seeds. 


\section{Table 8}

Dry weight (DW) per plant obtained with small $(S-0.84 \geq 1.0 \mathrm{~mm})$, medium $(\mathrm{M}-1.0 \geq 1.41 \mathrm{~mm})$, and large $(\mathrm{L}->1.41 \mathrm{~mm})$ parsley seeds from eight lots of Portuguesa and Chacareira cultivar

\begin{tabular}{|c|c|c|c|c|c|c|c|c|c|}
\hline \multirow{2}{*}{ Cultivar } & & \multicolumn{8}{|c|}{ Lots } \\
\hline & & 1 & 2 & 3 & 4 & 5 & 6 & 7 & 8 \\
\hline \multirow{3}{*}{$\begin{array}{c}\text { 'Portuguesa' } \\
\text { DW (g) }\end{array}$} & S & 0.21 a $A$ & 0.02 a D & 0.04 a D & 0.06 a CD & 0.05 a CD & 0.07 b BCD & $0.11 \mathrm{ab} B C$ & 0.13 a B \\
\hline & M & $0.13 \mathrm{~b} A B C$ & 0.06 a D & 0.07 a BCD & 0.07 a CD & 0.09 a BCD & 0.16 a A & 0.13 a $A B$ & 0.08 a BCD \\
\hline & L & $0.06 \mathrm{c} \mathrm{AB}$ & 0.04 a B & 0.07 a AB & 0.06 a $A B$ & 0.08 a AB & $0.09 \mathrm{~b} A \mathrm{AB}$ & $0.07 \mathrm{~b}$ AB & 0.12 a A \\
\hline \multirow{3}{*}{$\begin{array}{c}\text { 'Chacareira' } \\
\text { DW (g) }\end{array}$} & S & $0.18 \mathrm{~b}$ AB & 0.19 a A & 0.09 a C & 0.13 a $A B C$ & 0.13 a $A B C$ & 0.11 a BC & 0.08 a C & 0.12 a BC \\
\hline & M & 0.26 a A & $0.14 a b$ BCD & 0.06 a E & 0.19 a $A B$ & 0.10 a CDE & 0.06 a DE & 0.10 a CDE & 0.15 a BC \\
\hline & L & $0.19 \mathrm{~b} \mathrm{~A}$ & 0.09 b BC & 0.10 a BC & 0.14 a $A B$ & 0.08 a BC & 0.06 a C & 0.10 a BC & 0.13 a $A B C$ \\
\hline
\end{tabular}

Means followed by the same lowercase letter in the column and uppercase letter in the row do not differ statistically from each other based on Tukey test at $5 \%$ probability.

In seeds of Chacareira cultivar, there was no difference between seeds of different sizes in the dry weight mass for lots $3,4,5,6$, 7 , and 8 . For lots 1 and 2 , the best results were obtained with medium-sized seeds, and in lot 2 , there was a difference between medium and small seeds.

Therefore, it was revealed that though large seeds yielded higher number of plants, they did not present superiority in terms of fresh and dry weight. The competition between the plants probably minimized the effect of the seed size, since the spacing between plants was not the ideal one for parsley. The crop was not thinned because the focus of the research was to evaluate the physiological potential of seeds. El-Zaeddi et al. (2016) and Resende, Yuri and Costa (2016) reported for parsley and carrot crops that bigger stands resulted in higher yield, even though the latter had less dry root weight.

According to the results for both studied cultivars, seeds classified with sieves with larger mash opening provide lots with higher physiological quality and greater success on stand establishment than those with smaller mesh opening, pointing the practical advantage of the classification of parsley seeds by size on a commercial scale.

\section{Conclusion}

The parsley seeds classified by the $1.41 \mathrm{~mm}$ sieves presented higher vigor, and consequently, greater success in stand establishment in the field.

The use of sieves in the classification of parsley seeds helps in obtaining lots with superior physiological traits.

\section{Acknowledgment}

This research was conducted with the support of the Coordination for the Improvement of Higher Education Personnel Brazil (CAPES) - Financing Code 001. 


\section{References}

Bisognin, M. B., Kulczynski, S. M., Ferrari, M. Gaviraghi, R., Pelegrin, A. J., \& Souza, V. Q. (2016). Desempenho fisiológico de sementes olerícolas em diferentes tempos de hidrocondicionamento. Revista de Ciências Agrárias, 39(3), 349-359. doi: 10.19084/RCA15163

Cardoso, A. I. I., \& Silva, N. (2009). Influência do cultivar e do tamanho das sementes na produção de couve-flor. Revista Ceres, 56(6), 777-782. Retrieved from http://www. ceres.ufv.br/ojs/index.php/ceres/article/ view/3507/1397

Carvalho, N. M. E., \& Nakagawa, J. (2012). Sementes: ciência, tecnologia e produção. Jaboticabal, SP: Funep.

Corrêa, L. C., Fo., Martinazzo, A. P., Teodoro, C. E. S., \& Andrade, E. T. (2018). Post-harvest of parsley leaves (Petroselinum crispum): Mathematical modelling of drying and sorption processes. Revista Brasileira de Engenharia Agrícola e Ambiental, 22(2), 131-136. doi: 10.1590/1807-1929/ agriambi.v22n2p131-136

El-Zaeddi, H., Calín-Sánchez, Á., MartínezTomé, J., Nogueira-Artiaga, L., Burló, F., \& Carbonell-Borrachina, Á. A. (2016). Irrigation dose and plant density affect the essential oil content and sensory quality of parsley (Petroselinum sativum). Scientia horticulturae, 206(1), 1-6. doi: 10.1016/j. scienta.2016.04.028

Gomes, T. A. R., Casaroli, D., Fagan, E. B., Soares, L. H., Rocha, F. J., \& Rosa, T. F. A. (2012). Influence of the size of seeds in the productivity of culture of carrot. Cerrado Agrociências, 3(3), 72-82. Retrieved from https://revistas.unipam.edu.br/index.php/ cerradoagrociencias/issue/view/73
Hanumaiah, L., \& Andrews, H. (1973). Effects of seed size in cabbage and turnip on performance of seeds, seedlings and plants. Proceedings of the Association of Official Seed Analysts, 63, 117-125. Retrieved from https://www.jstor.org/ stable/23432503?seq=1

Jeromini, T. S., Martins, C. C., Pereira, F. E. C. B., \& Gomes, F. G., Jr. (2019). The use of X-ray to evaluate Brachiaria brizantha seeds quality during seed processing. Revista Ciência Agronômica, 50(3), 439-446. doi: 10.5935/1806-6690.20190052

Maodaa, S. N., Allam, A. A., Ajarem, J., AbdelMaksoud, M., Al-Basher, G. I., \& Wang, Z. Y. (2016). Effect of parsley (Petroselinum crispum, Apiaceae) juice against cadmium neurotoxicity in albino mice (Mus musculus). Behavioral and Brain Functions, 12(6), 1-16. doi: 10.1186/s129 93-016-0090-3

Marcos, J., Fo. (2015). Fisiologia de sementes de plantas cultivadas. Londrina, PR: Abrates.

Marcos, J., Fo., \& Kikuti, A. L. P. (2006). Vigor de sementes de rabanete e desempenho de plantas em campo. Revista Brasileira de Sementes, 28(3), 44-51. doi: 10.1590/ S0101-31222006000300007

Martins, C. C., Silva, N., \& Machado, C. G. (2013). Carrot seed size and progenies influence on seed physiological quality and plant productivity performance. Journal of Food, Agriculture \& Environment, 11(2), 1143-1147. doi: 10.1234/4.2013.4816

Melo, L. F., Martins, C. C., Silva, G. Z., Pereira, F. E. C. B., \& Jeromini, T. S. (2018). Effects of processing phases on the quality of massai grass seeds. Revista Ciência Agronômica, 49(2), 259-266. doi: 10.5935/ 1806-6690.20180029 
Ministério da Agricultura, Pecuária e Abastecimento (2009). Regras para análise de sementes. Brasília: Mapa/ACS.

Miranda, R. M., Dias, D. C. F. S., Picoli, E. A. T., Silva, P. P., \& Nascimento, W. M. (2017). Physiological quality, anatomy and histochemistry during the development of carrot seeds (Daucus carota L.). Ciência e Agrotecnologia, 41(2), 169-189. doi: 10. 1590/1413-70542017412009216

Oliveira, S. S. C., Martins, C. C., Pereira, F. E. C. B., Lopes, M. T. G., \& Torres, S. B. (2017). Tests for the selection of forage turnip progeny to order the vigor and longevity of seeds. Revista Caatinga, 30(1), 230-236. doi: 10.1590/1983-21252017v30n125rc

Pereira, F. E. C. B., Torres, S. B., Silva, M. I. L., Granjeiro, L. C., \& Benedito, C. P. (2014). Physiological quality of pepper seeds in relation to age and period of post-harvest resting. Revista Ciência Agronômica, 45(4), 737-744. doi: 10.1590/S1806-6690 2014000400011

Pereira, R. S., Nascimento, W. M., \& Vieira, J. V. (2008). Carrot seed germination and vigor in response to temperature and umbel orders. Scientia Agricola. 65(2), 145-150. doi: 10.1590/S0103-90162008000200006
Pereira, W. A., Pereira, S. M. A., \& Dias, D. C. F. S. (2013). Influence of seed size and water restriction on germination of soybean seeds and on early development of seedlings. Journal of Seed Science, 35(3), 316-322. doi: 10.1590/S2317-1537 2013000300007

Resende, G. M., Yuri, J. E., \& Costa, N. D. (2016). Planting times and spacing of carrot crops in the São Francisco Valley, Pernambuco state, Brazil. Revista Caatinga, 29(3), 587593. doi: 10.1590/1983-21252016v29 n308rc

Santos, V. J., Garcia, D. C., Lopes, S. J., \& Eichelberger, L. (2010). Physiological quality of carrot seeds classified by size. Ciência Rural, 40(4), 1903-1908. doi: 10. 1590/S0103-84782010000900008

Silva, P. P., Sekita, M. C., Dias, D. C. F. S., \& Nascimento, W. M. (2016). Biochemical and physiological analysis in carrot seeds from different orders of umbels. Revista Ciência Agronômica, 47(2), 407-413. doi: 10.5935/1806-6690.20160049 